\title{
Alternatif Penyelesaian Sengketa Pertanahan Melalui Proses Mediasi di Badan Pertanahan Kota Makassar
}

\author{
Hasnan Hasbi
}

Fakultas Hukum, Universitas Muslim Indonesia

Email Correspondensi: hasnanhasbi02@gmail.com

No. Handphone Correspondensi : (+62) 821-8777-0031

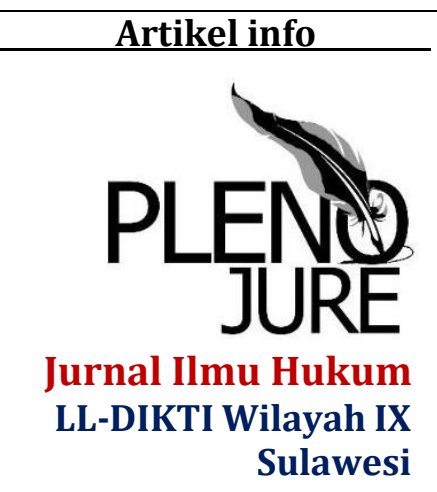

Artikel history:

Received ; 23 Januari 2020

Revised : 22 Maret 2020

Accepted ; 23 Maret 2020

\begin{abstract}
Abstrak. Penelitian ini bertujuan untuk mengetahui bagaimana penyelesaian sengketa pertanahan melalui proses mediasi di BPN Kota Makassar dan Bagaimana Peranan mediator dalam penyelesaian sengketa pertanahan melalui proses mediasi. Mediasi adalah suatu alternatif dalam menyelesaikan suatu kasus atau sengketa antara para pihak yang sedang berperkara, berkonflik atau dalam bahasa umumnya adalah musyawarah untuk memutuskan suatu keputusan antara para pihak yang sedang berperkara, berkonflik. Metode penelitian yang digunakan adalah metode dengan jenis penelitian normatif-empiris, menggunakan 3 (tiga) tipe pendekatan yakni pendekatan perundang-undangan (statute approach), pendekatan peraturan kasus (case approach), dan pendekatan konseptual (conceptual approach). Hasil dari penelitian ini adalah untuk menjelaskan bagaimana penyelesaian sengketa pertanahan melalui proses mediasi di BPN Kota Makassar dan bagaimana peranan mediator dalam penyelesaian sengketa pertanahan melalui proses mediasi, agar keberadaan mediator dalam menjalankan perannya dapat diterima baik oleh para pihak yang telah menunjuknya demi tercapainya kesepakatan para pihak untuk berdamai demi meminimalisir penumpukan perkara di pengadilan. Dan sebagai saran dari permasalahan dalam bidang pertanahan untuk menyempurnakan dan menyesuaikan dengan jiwa Undang-Undang Nomor 5 tahun 1960 tentang pokok agraria dan Undang-Undang Nomor 30 Tahun 1999 tentang arbitrase dan alternatif penyelesaian sengketa, Peraturan Mahkamah Agung RI No.1 tahun 2016 agar persoalan pertanahan dapat diselesaikan secara non litigasi atau tanpa proses hukum di pengadilan karena model penyelesaian ini tidak memakan waktu yang lama, proses cepat dan biaya yang kecil.
\end{abstract}

Abstract. This study aims to find out how the settlement of
land disputes through the mediation process in the Makassar
City BPN and How the role of mediators in the resolution of
land disputes through the mediation process. Mediation is an
alternative in resolving a case or dispute between parties
who are in litigation or general language is a deliberation to
decide on a decision between the parties. The research 
method used is normative-empirical, using 3 (three) types of approaches namely the statute approach, case approach, and conceptual approach. The results of this study are to explain how the resolution of land disputes through the mediation process in the Makassar City BPN and how the role of mediators in the resolution of land disputes through the mediation process, to minimize the accumulation of cases in court. And as a suggestion of problems in the field of land to perfect and following the spirit of law no.5 of 1960 on agrarian issues and Law No.30 of 1999 concerning arbitration and alternative dispute resolution, so that land issues can be resolved non-litigation or without due process in the court because this settlement model does not take long, fast process and small cost.

Keywords:

Mediasi;

Pertanahan;

Penyelesaian

Sengketa;

\section{PENDAHULUAN}

Indonesia sebagai Negara agraris masih diliputi oleh permasalahan dalam bidang Pertanahan dengan melahirkan sengketa Pertanahan, karena saat ini tanah telah memiliki nilai ekonomis bagi pemiliknya. Di bidang pertanahan jika dilihat dari sisi positifnya maka nilai atas sebidang tanah yang telah memiliki nilai ekonomis bagi pemiliknya akan sangat menguntungkan pemiliknya, namun dari nilai (value) terhadap sebidang tanah memberikan suatu dampak negatif dengan terkadang masyarakat Indonesia saling mengklaim kepemilikan suatu tanah yang menimbulkan konflik dan sengketa dalam bidang pertanahan yang berkepanjangan. Berdasarkan catatan Badan Pertanahan Nasional RI, sedikitnya ada 7491 kasus permasalahan tanah yang saat ini sedang ditanganinya. Dengan jumlah kasus tersebut permasalahan tanah menjadi hal yang terpenting untuk segera diselesaikan, mengingat permasalahan dibidang pertanahan semakin menjadi perhatian serius yang dapat mengakibatkan akan berkurangnya kepercayaan masyarakat terhadap perlindungan hukum, ${ }^{1}$ bagi mereka yang memiliki hak atas tanah.

Penumpukan permasalahan tanah maupun pengaduan di Kantor Badan Pertanahan Nasional RI, maupun kantor wilayah Badan Pertanahan Nasional yang berada ditiap-tiap Provinsi sangatlah beralasan karena masih kurangnya kesadaran masyarakat untuk menempuh jalur damai atau bermusyawarah membicarakan solusi dari persoalan yang dihadapinya. Kurangnya pemahaman dan keahlian dari Pegawai Badan Pertanahan Nasional RI maupun Provinsi, Kota Dan Kabupaten yang membidangi, mengurusi pengaduan masyarakat untuk mengakomodir kepentingan-kepentingan masyarakat yang dapat ditengahi untuk tercapainya suatu perdamaian yang mesti diawali dengan mengedukasi para pihak yang sedang berkonflik. Dengan mengakomodir aduan masyarakat maka faktor dalam meminimalisir

\footnotetext{
${ }^{1}$ Ali, A. (2008). Menguak tabir hukum. Jakarta: Ghalia Indonesia.
} 
segala bentuk permasalahan-permasalahan tanah dengan cara-cara kekeluargaan dapat berhasil,2 selain itu mengadakan atau menggelar pertemuan khusus kepada para pihak yang diadukan dan menawarkan proses mediasi kepada para pihak yang bersengketa agar salah satu tujuan hukum yang ingin dicapai yaitu keadilan dengan mediasi seluruh pihak akan merasakan keadilan atas sebuah kesepakatan yang dibuatnya tanpa ada paksaan dari pihak lain, namun pegawai BPN perlu terlebih dahulu mengedukasi secara baik kepada para pihak akan mereka memahami kedudukannya dalam proses mediasi untuk mencari solusi dari permasalahan yang sedang dihadapi oleh para pihak.

Di Indonesia masalah dalam bidang pertanahan sering muncul dengan berbagai macam persoalan, kesalahan obyek tanah mengenai data fisik dan data yuridis, kesalahan dalam penunjukkan batas-batas tanah dan peta lokasi yang dimiliki oleh pihak kantor Badan Pertanahan daerah setempat yang tidak sesuai dengan fakta di lokasi tanah tersebut dan kesalahan kepemilikan hak atas tanah. Untuk masalah Pertanahan sebenarnya dapat diselesaikan dengan cara-cara yang identik dengan masyarakat Indonesia yaitu dengan cara musyawarah mufakat untuk menyelesaikan konflik, sengketa, perbedaan pendapat dan perselisihan. ${ }^{3}$ Dikemukakan oleh Coser bahwa "conflicts involve struggles between two or more people over values, or competition for status, power, or scarce resources. Jika konflik telah nyata (manifest), maka hal itu disebut sengketa (Cristopher W 1996, 2-3). Sedangkan sengketa merupakan pernyataan publik mengenai tuntutan yang tidak selaras atau inconsistent terhadap sesuatu yang benilai, sedangkan konflik merupakan pertentangan yang bersifat makro, misalnya pertentangan antara golongan atau kelompok (Friedman M 2001, 11-12).

Di setiap daerah dalam Wilayah Indonesia persoalan kepemilikan tanah masih menjadi hal yang sangat serius bagi masyarakatnya, keberadaan tanah yang belum jelas kepemilikannya dan masih kurangnya kesadaran masyarakat terhadap proses yang harus ditempuh mengakibatkan persoalan yang timbul karena sengketa maupun konflik pertanahan harus menumpuk dipengadilan setempat. ${ }^{4}$ Bisa dilihat dengan ketentuan hukum acara yang ada saat ini untuk menyelesaikan kasus-kasus konflik dan sengketa tanah, yang bersifat perdata, penyelesaian oleh pengadilan dilakukan berdasarkan ketentuan Herziene Inlandsch Reglement (HIR) sebagai salah satu sumber hukum acara perdata bagi daerah Pulau Jawa dan Madura peninggalan kolonial Hindia Belanda yang masih berlaku di Indonesia hingga kini, dan atau Rechtsreglement voor de Buitengewesten (RBg) yang merupakan Hukum Acara Perdata bagi daerahdaerah luar pulau Jawa dan Madura. Sedangkan penyelesaian secara di luar pengadilan dengan menggunakan mekanisme alternatif penyelesaian sengketa atau Alternative Dispute Resolution (ADR). Penyelesaian sengketa tanah menggunakan mekanisme ADR dilakukan berdasarkan Undang-Undang No.30 Tahun 1999 tentang Arbitrase dan Alternatif Penyelesaian Sengketa.

langkah yang dilakukan oleh pihak Badan Pertanahan dalam melakukan

\footnotetext{
${ }^{2}$ Hasbullah, F. H. (2009). Hukum Kebendaan Perdata Hak-Hak Yang Memberi Jaminan. Indo Hill-Co, Jakarta. ${ }^{3}$ Hajati, S., Sekarmadji, A., \& Winarsih, S. (2014). Model Penyelesaian Sengketa Pertanahan Melalui Mediasi Dalam Mewujudkan Penyelesaian Yang Efisiensi Dan Berkepastian Hukum. Jurnal Dinamika Hukum, 14(1), 36-48.

${ }^{4}$ Umar, M. H. (2013). BANI dan penyelesaian sengketa. PT. Fikahati Aneska bekerjasama dengan BANI Arbitration Center (Badan Arbitrasi Nasional Indonesia).
} 
mediasi antara para pihak yang keberatan dianggap masih kurang diinginkan, semestinya persoalan itu bisa diselesaikan secara musyawarah untuk mufakat dengan mengedepankan asas kekeluargaan, efesiensi biaya yang dikeluarkan, ${ }^{5}$ dan meminimalisir konflik didaerah dengan mengefektifkan Proses mediasi di kantor Pertanahan ditiap-tiap daerah.

Perlu diketahui Musyawarah untuk mufakat menjadi sistem dalam budaya Pancasila yang sejak zaman dahulu masyarakat Indonesia telah mengenal musyawarah mufakat didalam menyelesaikan konflik, sengketa, perbedaan pendapat dan perselisihan antara kedua bela pihak atau lebih. Sebab masyarakat Indonesia yang sangat beragam sudah menjadi hal yang pasti disetiap keputusan atau kebijakan dalam berbangsa dan bernegara yang berbeda akan menuai kontra dari masyarakat yang merasa tidak setuju atau tidak sepakat menerima suatu keputusan atau kebijakan yang diambil oleh seseorang atau orang lain, baik dari pemerintah maupun antar sesama masyarakat.

Musyawarah mufakat merupakan falsafah masyarakat Indonesia dalam setiap pengambilan keputusan, termasuk menyelesaikan sengketa. Dalam UUD 1945 Sila Ke-4 dan peraturan perundang-undangan lainnya telah mengatur sedemikian sempurnanya regulasi yang mengatur hal-hal yang dibahas saat ini. Namun kesempurnaan peraturan dan ciri khas dari masyarakat Indonesia telah terkikis oleh pengaruh-pengaruh modernisasi, keegoisan masyarakat dan rasa ingin menang sendiri, sehingga ciri khas masyarakat Indonesia yang selalu mengutamakan musyawarah mufakat telah sangat sulit didapatkan di zaman saat ini.

Namun Hukum di Indonesia menemukan formula baru didalam penyelesaian konflik atau sengketa pertanahan meski tidak menempuh jalur hukum, belakangan ini perkembangan hukum di Indonesia menyesuaikan tingkat kebutuhan masyarakat untuk menyelesaikan suatu konflik. Cara ini sangat mirip dengan cara penyelesaian sengketa atau konflik yang masyarakat Indonesia sering lakukan dengan cara musyawarah mufakat.

Cara penyelesaian konflik atau sengketa tanpa proses hukum di pengadilan dikenal dengan sebutan mediasi, pengetahuan mediasi pun masih sangat baru bagi masyarakat Indonesia karena masih kurang disosialisasikannya kepada masyarakat mengenai ketentuan-ketentuan tentang mediasi. Mediasi yang substansinya adalah kesepakatan demi tercapainya perdamaian, ${ }^{6}$ pada prinsipnya secara hukum sudah diperkenalkan di Indonesia sejak tahun 2003, yaitu proses mediasi pada lembaga peradilan. Pemerintah melalui Mahkamah Agung mengeluarkan Peraturan Mahkamah Agung (Perma) No. 3 tahun 2003 dan diperbaharui dengan Peraturan Mahkamah Agung RI No.1 Tahun 2016 tentang prosedur mediasi di Pengadilan. Peraturan ini dilatar belakangi adanya realitas sosial dimana pengadilan sebagai lembaga yang diharapkan mampu menyelesaikan perkara dengan memberikan rasa keadilan bagi para pihak tidak mampu menyelesaikanya sesuai dengan asas cepat dan biaya ringan, dengan masih

\footnotetext{
${ }^{5}$ Aswari, A. (2018). Peran Ganda Administrator sebagai Mediator dalam Sengketa Transaksi Ponsel Bekas secara Online. Jurnal Ilmiah Kebijakan Hukum, 12(3), 259-274.

${ }^{6}$ Malik, A. (2012). Mediasi: Problem Solving Technique Dalam Tiga Wajah Hukum Indonesia. Jurisdictie.
} 
menyisahkan persoalan klasik yaitu penumpukan perkara. ${ }^{7}$ Dan dalam proses mediasi akan ditunjuk seorang mediator berlisensi (yang telah diberikan izin) yang disepakati oleh para pihak yang berselisih, bersengketa atau berkonflik untuk ditengahi dalam menuangkan segala kepentingannya untuk mencari solusi dari permasalahan para pihak. Olehnya penulis merumuskan permasalahan tentang penyelesaian sengketa pertanahan melalui proses mediasi di BPN Kota Makassar dan bagaimana peranan mediator dalam penyelesaian sengketa pertanahan melalui proses mediasi.

\section{METODE}

Penelitian ini dilaksanakan di BPN Kota Makassar dan Penelitian ini berlangsung selama 5 bulan dari Bulan September 2018 - Januari 2019. Dengan adanya penelitian ini diharapkan agar praktisi hukum yang membidangi aduan perselisihan, sengketa pertanahan di Badan Pertanahan Nasional dan seluruh masyarakat memahami penyelesaian sengketa pertanahan melalui proses mediasi agar penumpukan perkara di pengadilan dapat diminimalisir. Penelitian ini adalah merupakan penelitian kuantitatif dengan menggunakan pendekatan hukum normatif dan hukum empiris dengan melalui dua tataran yakni pada tataran dogmatik hukum dan tataran teori hukum. ${ }^{8}$

Bahan hukum primer dan bahan hukum sekunder digunakan untuk merampungkan suatu karya ilmiah, melalui penelusuran atau inventarisasi bahan hukum baik bahan hukum primer maupun bahan hukum sekunder. Inventarisasi bahan hukum ini dimulai dengan mengidentifikasi bahan hukum, dilanjutkan dengan klasifikasi atau pemilahan bahan hukum, dan diteruskan dengan pemilahan bahan hukum secara sistematis dan logis. Bahan hukum akan diperoleh dari peraturan perundang-undangan nasional. Data primer dan data sekunder yang telah terkumpul kemudian diolah dan dianalisis secara kualitatif dan menggunakan metode deduktif. Analisis secara kualitatif dalam hal ini adalah suatu analisis yang mengkaji secara mendalam data yang ada kemudian digabungkan dengan data yang lain, lalu dipadukan dengan teori-teori yang mendukung dan selanjutnya ditarik kesimpulan.

\section{HASIL DAN PEMBAHASAN}

Badan Pertanahan Nasional mempunyai tugas menyelenggarakan urusan pemerintahan di bidang pertanahan dan mampu bertindak secara administratif menyelesaikan sengketa pertanahan yang menjadi kewenangan yang mendasar sesuai Peraturan Menteri Agraria Dan Tata Ruang / Kepala BPN No.11 Tahun 2016 Objek yang menjadi kewenangan BPN disebutkan dalam Pasal 11 ayat (3) antara lain mengenai suatu tumpang tindih hak kepemilikan atas tanah. Dalam hal ini yaitu atas objek hak yang sama terdapat dua kepemilikan oleh dua orang (atau lebih) yang berbeda. Tujuan penyelesaian sengketa oleh BPN berdasarkan instrument hukum tersebut adalah untuk memberikan kepastian hukum dan keadilan mengenai penguasaan, pemilikan, penggunaan dan pemanfaatan tanah agar

\footnotetext{
${ }^{7}$ Subhan, M. H. (2008). Hukum Kepailitan, Prinsip, Norma dan Praktik di Peradilan. Jakarta: Prenada Media Group.

${ }^{8}$ Marzuki, P. M. (2005). Penelitian Hukum. Jakarta : Prenada Media Group.
} 
perlindungan hukum terhadap pemilik sah terhadap tanah dapat terjamin. Demi mewujudkan tujuan tersebut maka BPN memberikan ruang bagi para pihak yang bersengketa atau berkonflik atas suatu tanah agar menempuh penyelesaian sengketa pertanahan melalui mediasi, penyelesaian sengketa yang mengedepankan prinsip musyawarah untuk mufakat bagi kebaikan semua pihak.

Ketentuan hukum yang mengaturnya tertuang dalam Peraturan Menteri Agraria Dan Tata Ruang / Kepala BPN No.11 Tahun 2016 untuk menempuh penyelesaian sengketa secara non litigasi atau tanpa proses di pengadilan, selain itu peraturan tersebut yang mendasari diberikannya kewenangan khusus bagi pihak BPN untuk menjadi mediator di instansinya dengan membekali pegawainya keahlian sebagai mediator dengan memiliki lisensi atau telah mengikuti pendidikan mediator. Dengan ditunjuknya pihak BPN sebagai mediator, maka didalam melakukan proses penyelesaian sengketa melalui mediasi seorang mediator akan bertindak netral, mediator tidak terjadi konflik kepentingan (conflict of interest) dengan para pihak yang sedang bersengketa dan mediator tidak dapat melakukan keputusan sepihak yang merugikan salah satu pihak atau merugikan juga para pihak atas kepentingan seorang mediator.

Proses mediasi di BPN akan diawali dengan adanya laporan masyarakat atau pengaduan, yang dilakukan sendiri oleh pihak yang merasa dirugikan, kelompok masyarakat yang merasa dirugikan, pemerintah setempat yang dapat mengakomodir kegelisahan masyarakat setempat di suatu obyek tanah yang sengketa, ${ }^{9}$ dan dapat juga dilakukan oleh Lembaga Penegak Hukum untuk mengawali laporan ke BPN agar dilakukan pengecekan status tanah yang sedang dipersengketakan yang mengakibatkan konflik oleh pelapor dan terlapor, pengadu dan teradu. Pengaduan ini ialah langkah untuk mengetahui awal dari sebuah permasalahan yang sedang dihadapi oleh para pihak agar sesuatu yang masih belum jelas dapat diberikan penjelasan oleh pihak berwenang yang dalam hal ini mewakili pemerintah membidangi urusan pertanahan ialah BPN.

Mediasi digunakan sebagai mekanisme penyelesaian sengketa pertanahan oleh BPN. Di dalam Pasal 4 Peraturan Menteri Agraria Dan Tata Ruang / Kepala BPN No.11 Tahun 2016 dasar penyelesaian dibedakan berdasarkan datangnya laporan. Dalam hal ini, laporan dapat berasal dari "Inisiatif Kementerian" atau "Pengaduan Masyarakat". Pihak BPN akan melakukan inisiatif untuk menyelesaikannya jika permasalahan tanah tersebut memiliki unsur sebagai berikut : a) menjadi perhatian masyarakat; b) melibatkan banyak pihak; c) mempunyai nilai yang tinggi baik dari segi sosial, budaya, ekonomi, kepentingan umum, pertahanan dan keamanan; dan/atau d) permintaan instansi yang berwenang atau penegak hukum.

Setelah menerima laporan atau aduan pihak BPN menunjuk tim yang akan menganalisis terhadap data-data maupun bukti-bukti yang mendasari dimasukkannya laporan atau pengaduan ke pihak BPN setempat. Kemudian dilakukan pemisahan data hasil analisis yang mana menjadi kewenangan BPN

9 Munawar, A. (2019). Konflik Lahan Dan Alternatif Solusi Pada Areal Iuphkm Gapoktan Tandung Billa Kota Palopo. Journal TABARO Agriculture Science, 2(2), 257-269. 
sesuai Peraturan Menteri Agraria dan Tata Ruang / Kepala BPN No.11 Tahun 2016. Maka hasil analisis data-data oleh tim BPN akan disampaikan pada agenda pertemuan dengan para pihak yang melaporkan atau mengadukan dan pihak yang dilaporkan atau yang diadukan. Setelah pertemuan itu dilaksanakan dan dihadiri oleh para pihak maka dalam hal proses mediasi di BPN akan ditunjuk seorang mediator untuk menjadi penengah dalam proses mediasi tersebut tujuannya untuk melahirkan perdamaian atau kesepakatan para pihak yang bersengketa. Jika salah satu pihak tidak hadir, atau kedua belah pihak tidak hadir maka pertemuan dan proses mediasinya dapat ditunda dengan memberikan penyampaian ulang melalui surat atau undangan yang dikirimkan oleh pihak BPN kepada para pihak. Jika proses mediasi telah dilaksanakan dan telah menemui kata sepakat untuk berdamai, maka mediator akan membuat berita acara mediasi dengan para pihak dan membuat akta perdamaian yang berisi kesepakatan para pihak dari proses mediasi untuk para pihak tunduk dan mampu menjalankan isi kesepakatan dari hasil mediasi yang dilakukan oleh pihak Badan Pertanahan Nasional (BPN) setempat.

Yang mesti diketahui bahwa proses mediasi di BPN sifatnya sukarela bagi para pihak tanpa ada unsur paksaan, seperti yang termaktub dalam ketentuan Pasal 37 ayat (2) Peraturan Menteri Agraria Dan Tata Ruang / Kepala BPN No.11 Tahun 2016 disebutkan, jika salah satu pihak menolak untuk dilakukan Mediasi maka penyelesaiannya diserahkan kepada para pihak sesuai dengan ketentuan peraturan perundang-undangan yang berlaku di Indonesia. Selain itu pada Pasal 38 ayat (1) dan (2), bahwa Pelaksanaan Mediasi dilakukan paling lama 30 (tiga puluh) hari, dan mediatornya berasal dari BPN Pusat, Kantor Wilayah BPN dan/atau Kantor Pertanahan disebut dalam Pasal 39 ayat (1) huruf c.

Dalam hal Mediasi menemukan kesepakatan, dibuat Perjanjian Perdamaian berupa akta perdamaian berdasarkan berita acara mediasi yang mengikat para pihak. Sesuai bunyi pasal 41 ayat (1) dan (2) Peraturan Menteri Agraria Dan Tata Ruang / Kepala BPN No.11 Tahun 2016 "Perjanjian Perdamaian didaftarkan pada Kepaniteraan Pengadilan Negeri setempat sehingga mempunyai kekuatan hukum mengikat". Dengan ketentuan paling lama 30 hari proses mediasi dilakukan, setelah itu sesuai pasal 23 ayat (5) maka pihak BPN akan membuat Keputusan untuk penyelesaian sengketa atau konflik dilaksanakan oleh Kepala Kantor Pertanahan, dengan dinyatakan bahwa "Pejabat yang bertanggungjawab atau Tim Penyelesaian Sengketa dan Konflik, menyampaikan Laporan Penyelesaian Kasus Pertanahan kepada Kepala Kantor Wilayah BPN atau Menteri". Selanjutnya bahwa "Setelah menerima Laporan Penyelesaian Sengketa dan Konflik, Kepala Kantor Wilayah BPN atau Menteri menyelesaikan Sengketa dan Konflik menerbitkan a) Keputusan Pembatalan Hak Atas Tanah; b) Keputusan Pembatalan Sertifikat; c) Keputusan Perubahan Data pada Sertifikat, Surat Ukur, Buku Tanah dan/atau Daftar Umum lainnya; atau d) Surat Pemberitahuan bahwa tidak terdapat kesalahan administrasi" Pasal 24 ayat (1) Peraturan Menteri Agraria Dan Tata Ruang / Kepala BPN No.11 Tahun 2016 dan terhadap keputusan itu wajib dilaksanakan kecuali terdapat alasan yang sah untuk menunda pelaksanaannya. Terdapat tiga alasan yang sah untuk menunda pelaksanaan penyelesaian sengketa atau konflik yaitu : a) sertifikat yang akan dibatalkan sedang dalam status diblokir atau disita oleh kepolisian, kejaksaaan, pengadilan 
dan/atau lembaga penegak hukum lainnya; atau b) tanah yang menjadi obyek pembatalan menjadi obyek hak tanggungan; atau c) tanah telah dialihkan kepada pihak lain. (Pasal 24 ayat (1) Peraturan Menteri Agraria Dan Tata Ruang / Kepala BPN No.11 Tahun 2016.

Alternatif penyelesaian sengketa pertanahan melalui proses mediasi dapat berjalan efektif dan dibutuhkan bagi masyarakat, jika dalam pelaksanaannya mediator dapat menjelaskan tujuan mediasi dan memberikan pemahaman tentang mediasi kepada para pihak dan pemerintah senantiasa memberikan sosialisasi kepada masyarakat tentang mediasi, sehingga masyarakat teredukasi untuk memahami secara luas tentang penyelesaian permasalahan pertanahannya dengan proses mediasi. ${ }^{10}$ Menggunakan cara mediasi dalam menyelesaikan permasalahan di bidang pertanahan akan menimbulkan kepuasan bagi para pihak yang bersengketa sebab dilakukan berdasarkan kehendak masing-masing untuk dituangkan dalam bentuk kesepakatan agar menghindari sengketa yang berkepanjangan dan menimbulkan biaya yang besar. ${ }^{11}$

Proses mediasi di BPN seorang mediator ikut membantu mencari berbagai alternatif penyelesaian sengketa, mediator dalam hal ini mendorong agar para pihak mencapai kesepakatan-kesepakatan yang memenuhi rasa keadilan bagi para pihak, ${ }^{12}$ dan mendorong untuk para pihak berprinsip mengakhiri perselisihan maupun sengketa ini. Mediator tidak dapat memaksanakan kehendaknya agar para pihak menyetujui segala hal yang ditawarkan oleh mediator maupun salah satu pihak nantinya dalam proses mediasi yang sedang berjalan.

Mediator dalam hal ini bertindak impartial dan netral tidak mempunyai hubungan kekeluargaan dengan salah satu pihak yang akan dilakukan proses mediasi. Mediator juga berperan aktif dalam menjelaskan kedudukan masingmasing pihak yang sedang bermasalah sehingga memilih jalur Mediasi harus diketahui masyarakat tujuannya untuk memberikan rasa kekeluargaan maupun persaudaraan ditengah bermasyarakat walaupun sedang menghadapi sengketa antara para pihak, agar persoalan yang timbul ditengah masyarakat dapat diselesaikan dengan mengedepankan kepentingan bersama dan melahirkan win-win solution dengan begitu masyarakat akan tetap terjaga kedamaian dalam bermasyarakat dan meminimalisir konflik didaerah.

Mediator yang ditunjuk melakukan mediasi di BPN adalah Mediator independent yang memiliki sertifikat dari Mahkamah Agung RI dan mediator dari internal BPN meskipun tidak memiliki sertifikat yang penunjukannya berdasarkan pertimbangan dari Kepala kantor BPN atau pejabat internal. Mediator internal ini disebut juga sebagai mediator otoritatif yang dalam hal ini mewakili pemerintah untuk bidang keahliannya sehingga menggunakan kewenangannya mengundang para pihak yang sedang bersengketa atau berkonflik di bidang yang menjadi kewenangannya agar melalui proses

\footnotetext{
${ }^{10}$ Ardia, M., Windari, R. A., SH, M., Yuliartini, N. P. R., \& SH, M. (2018). Implementasi Perma No. 1 Tahun 2016 Tentang Prosedur Mediasi Di Pengadilan Terhadap Penyelesaian Perkara Perdata Di Pengadilan Negeri Singaraja Kelas Ib. Jurnal Komunitas Yustisia, 1(2).

${ }^{11}$ Rismawati, S. D., Askari, S., \& Husein, M. M. (2013). Hakim Dan Mediasi: Pemaknaan Hakim Terhadap Mediasi Perkara Perdata di Pengadilan Negeri Pekalongan. Jurnal Penelitian, 9(2).

12 Milana, R. (2016). Efektivitas Mediasi Berdasarkan Peraturan Mahkamah Agung Nomor 01 Tahun 2008 dalam Penyelesaian Perkara Perdata di Pengadilan Negeri Makassar Tahun 2011-2015 (Doctoral dissertation, Universitas Islam Negeri Alauddin Makassar).
} 
mediasi di instansinya

\section{SIMPULAN DAN SARAN}

Alternatif penyelesaian sengketa pertanahan melalui proses mediasi menurut penulis memberikan kesimpulan dari beberapa uraian yang telah dikemukakan diatas, sebagai berikut :

Proses yang dilakukan oleh instansi yang berwenang berdasarkan pada Peraturan Menteri Agraria dan Tata Ruang / Kepala BPN No.11 Tahun 2016 sudah tepat dan sesuai dengan pasal yang telah disebutkan didalamnya, sehingga dengan adanya legal standing pihak BPN mewakili pemerintah menyangkut bidang pertanahan memberikan pelayan publik kepada masyarakat yang membutuhkan penyelesaian sengketa pertanahan dengan proses cepat, penuh rasa kekeluargaan dan menengahi sengketa antara pihak agar terciptanya perdamaian maupun kesepakatan para pihak dengan cara melakukan mediasi sesuai dengan ketentuan peraturan yang berlaku.

Proses mediasi yang telah dilakukan oleh pihak BPN dengan ketentuan waktu mediasi paling lama 30 hari dapat sesegera mungkin untuk membuat keputusan terhadap suatu aduan agar kepercayaan dan kepastian segera diperoleh oleh pihak pengadu dan teradu.

Proses mediasi yang dilakukan oleh Instansi BPN telah membantu lembaga peradilan dalam hal ini Pengadilan Negeri setempat untuk meminimalisir angka pendaftaran Gugatan tentang Perbuatan Melawan Hukum menyangkut obyek sengketa pertanahan. Sehingga dengan proses mediasi diharapkan menghindari penumpukan perkara pertanahan di pengadilan setempat, dengan proses mediasi menghadirkan rasa kekeluargaan dan keadilan bagi para pihak yang telah bersengketa dalam bidang pertanahan.

Alternatif penyelesaian sengketa pertanahan melalui proses mediasi, menurut penulis masih jauh dari kesempurnaan karena masih adanya beberapa hal yang belum terlaksana dengan baik, antara lain sebagai berikut:

Proses mediasi atau tahapan mediasi, alur laporan atau mekanisme mediasi mestinya di tampilkan pada ruang pelayanan di tiap-tiap kantor Badan Pertanahan Nasional. Alat peraga berupa banner mestinya di pasang pada tiap sudut kantor agar masyarakat yang sedang mencari tahu tentang alternatif penyelesaian sengketa dapat teredukasi sejak awal, sehingga dari satu masyarakat yang melihat maupun membaca alur atau mekanisme alternatif penyelesaian sengketa mampu mengedukasi masyarakat yang lain, kerabat maupun keluarganya.

Proses pelaksanaan keputusan yang telah dibuat dalam hal menindak lanjuti temuan atas laporan atau aduan agar dapat dijalankan mengingat tumpuhan harapan pihak pengadu ada pada pena keadilan yang telah diputus oleh seorang pejabat yang ditunjuk berdasarkan ketentuan hukum yang berlaku sesuai Peraturan Menteri Agraria Dan Tata Ruang / Kepala BPN No.11 Tahun 2016.

Proses mediasi di BPN harus mempunyai SOP internal dalam hal mengundang para pihak untuk menghadiri mediasi sesuai dengan surat 
penyampaian dari BPN dan masa waktu dilakukannya mediasi. Mediator di BPN seharusnya mengacu pada PERMA No.1 Tahun 2016 yang ditunjuk sebagai mediator adalah seorang mediator yang telah mengikuti pendidikan maupun pelatihan mediator sehingga memiliki keahlian secara teoritis maupun praktik dibuktikan dengan sertifikat mediator dari Mahkamah Agung RI. BPN diharapkan giat melakukan sosialisasi kepada masyarakat dalam hal menyangkut sengketa pertanahan yang dapat dilakukan melalui proses mediasi di BPN agar masyarakat mengetahui proses tersebut.

\section{DAFTAR RUJUKAN}

Ali, A. (2008). Menguak tabir hukum. Jakarta: Ghalia Indonesia.

Ardia, M., Windari, R. A., SH, M., Yuliartini, N. P. R., \& SH, M. (2018). Implementasi Perma No. 1 Tahun 2016 Tentang Prosedur Mediasi Di Pengadilan Terhadap Penyelesaian Perkara Perdata Di Pengadilan Negeri Singaraja Kelas Ib. Jurnal Komunitas Yustisia, 1(2).

Aswari, A. (2018). Peran Ganda Administrator sebagai Mediator dalam Sengketa Transaksi Ponsel Bekas secara Online. Jurnal Ilmiah Kebijakan Hukum, 12(3), 259-274.

Hasbullah, F. H. (2009). Hukum Kebendaan Perdata Hak-Hak Yang Memberi Jaminan. Indo Hill-Co, Jakarta.

Hajati, S., Sekarmadji, A., \& Winarsih, S. (2014). Model Penyelesaian Sengketa Pertanahan Melalui Mediasi Dalam Mewujudkan Penyelesaian Yang Efisiensi Dan Berkepastian Hukum. Jurnal Dinamika Hukum, 14(1), 36-48.

Umar, M. H. (2013). BANI dan penyelesaian sengketa. PT. Fikahati Aneska bekerjasama dengan BANI Arbitration Center (Badan Arbitrasi Nasional Indonesia).

Malik, A. (2012). Mediasi: Problem Solving Technique Dalam Tiga Wajah Hukum Indonesia. Jurisdictie.

Marzuki, P. M. (2005). Penelitian Hukum. Jakarta : Prenada Media Group.

Milana, R. (2016). Efektivitas Mediasi Berdasarkan Peraturan Mahkamah Agung Nomor 01 Tahun 2008 dalam Penyelesaian Perkara Perdata di Pengadilan Negeri Makassar Tahun 20112015 (Doctoral dissertation, Universitas Islam Negeri Alauddin Makassar). 
Munawar, A. (2019). Konflik Lahan Dan Alternatif Solusi Pada Areal Iuphkm Gapoktan Tandung Billa Kota Palopo. Journal TABARO Agriculture Science, 2(2), 257-269.

Rismawati, S. D., Askari, S., \& Husein, M. M. (2013). Hakim Dan Mediasi: Pemaknaan Hakim Terhadap Mediasi Perkara Perdata di Pengadilan Negeri Pekalongan. Jurnal Penelitian, 9(2).

Subhan, M. H. (2008). Hukum Kepailitan, Prinsip, Norma dan Praktik di Peradilan. Jakarta: Prenada Media Group. 